\title{
Geographical Extraction and the Finnish- Swedish Health Differential in Finland
}

\author{
JAN SAARELA, D.Soc.Sc., Docent in Population Economics \\ FJALAR FINNÄS, Ph.D., Professor in Demography \\ Department of Social Sciences, \\ Åbo Akademi University, Vaasa, Finland
}

\begin{abstract}
Previous research concerned with the Finnish-Swedish mortality differential in Finland tends to have overlooked the fact that many Finnish speakers who live in the same coastal area as the Swedish speakers originate from parts of the country with high death rates. Using an extract from Statistics Finland's longitudinal employment statistics file, we find that geographical extraction is an important factor underlying variation in both mortality and disability retirement in working-aged people. Finnish speakers born in eastern and northern Finland have substantially poorer health than those originating from western Finland. It is consequently not sufficient to restrict analyses only by present region of residence. Still, there remains a between-group health differential also in people born in the coastal area, which suggests that health behaviors and risk factors could be relevant.
\end{abstract}

Keywords: mortality, disability retirement, geographical extraction, language groups, Finland

\section{Introduction}

People of the Swedish-speaking minority in Finland are known to have lower mortality rates than their Finnish-speaking counterparts (Sauli 1979; Valkonen 1982; Koskinen 1994; Martelin 1994). One would expect that regional variation underlies this health differential, since practically all of the 300,000 Swedish speakers live at the southern and western coastlines of the country, and mortality rates have traditionally been high in eastern and northern parts (Koskinen and Martelin 1994; Statistics Finland, 1997). To some extent this is true, but specifically in middle-aged men there remains a considerable difference between the two groups also when accounting for the impact of several structural and socio-economic confounders (Koskinen and Martelin 2003). Between-group comparisons of morbidity in terms of disability retirement arrive at similar conclusions (Saarela and Finnäs 2002). 
An important aspect to bear in mind in this context is that Finnish speakers and Swedish speakers who reside in the same area differ on geographical extraction. This area, which consists of the regions Uusimaa, Turunmaa and Pohjanmaa (Figure 1), was almost entirely dominated by Swedish-speaking settlement one century ago. Nowadays, still over 95 percent of the Swedish speakers who live here have also been born here, owing to the fact that the population group has been very stable with regard to within-country migration. In contrast, half of the Finnish-speaking population who live in the same area have their geographical roots elsewhere in Finland. This is because there were great changes in the population composition during the post-war period, with an extensive in-migration of Finnish speakers specifically from eastern and northern parts to the southern part of the country. However, Swedish speakers have been overrepresented among people moving abroad. In the 1950s and 1960s, about 60,000 of them left Finland for Sweden (Finnäs 1986).

Figure 1. Map of Finland, highlighting the area with Swedish-speaking settlements.

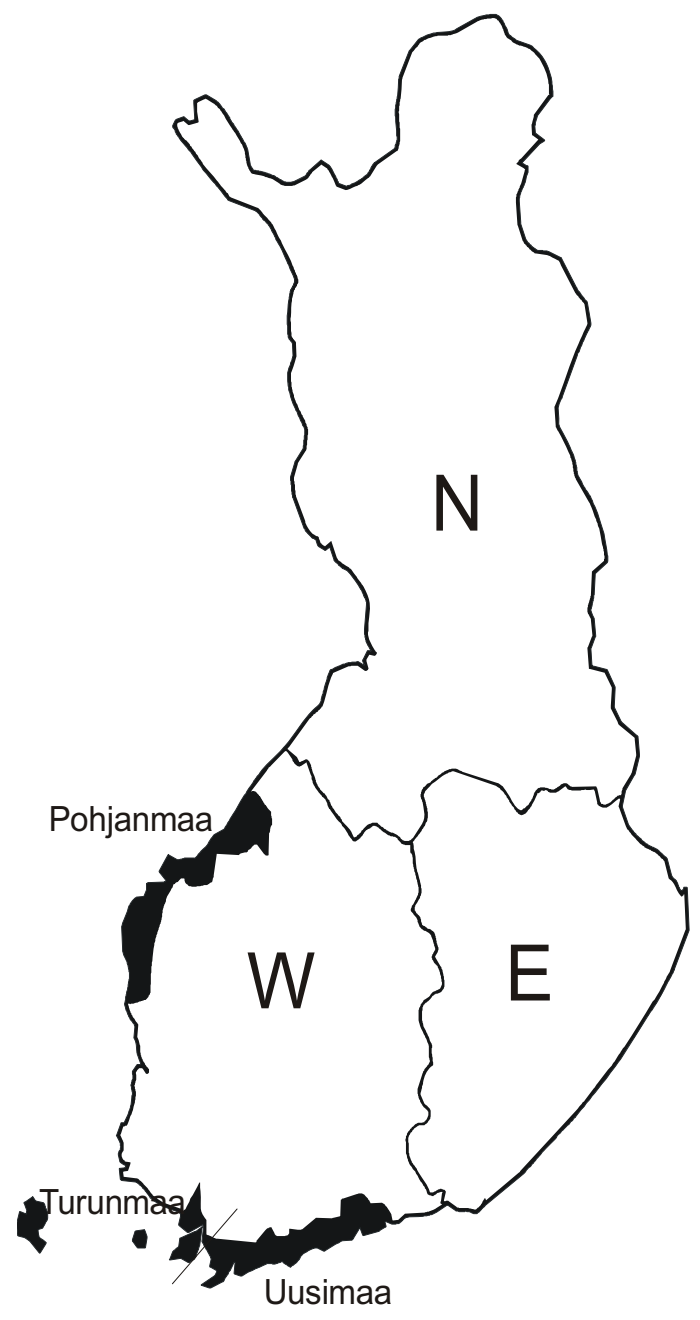

Notes: The shaded part refers to the specific area that is under study, which consists of municipalities with Swedish-speaking settlement. W=Western Finland, E=Eastern Finland, N=Northern Finland, as referred to in the text and in Table 1. 
Previous studies have shown that region of birth is a generally more decisive determinant of mortality than present region of residence (Valkonen 1987; Koskinen, 1994). This is a fact that has been overlooked by research concerned with the Finnish-Swedish health differential, however. Thus in order to understand this variation it is essential to consider the role of geographical extraction, which is the purpose of the present paper. In addition to mortality in working-aged people, we broaden the scope and include also disability retirement as an event of interest.

\section{Data and methodology}

\section{Data set}

The data set used is an extract from Statistics Finland's longitudinal employment statistics file (Statistics Finland 2005). It consists of annual individual-level information from the end of the years 1988 to 1999 about basic socio-economic, demographic and labor market related factors. A variable representing the unique mother tongue distinguishes Swedish speakers from Finnish speakers. Our extract has been designed to facilitate comparisons between the two population groups, being a stratified random sample with 20 percent of all Swedish speakers and 5 percent of all Finnish speakers born before 1984, who lived in bilingual or monolingual Swedish municipalities at any of the years mentioned. The total number of individuals to be analysed is 83,173 . The very few people born abroad are excluded from analysis.

There is information about whether a person died or became a disability pensioner. The data reveal that receiving disability pension significantly increases the mortality risk. Disability retirement is therefore, in addition to mortality, evidently a suitable indicator of poor health. Studying each event also facilitates empirical analysis as compared with analyzing mortality only, because disability retirement is much more common in working ages. We do not, however, know the specific reasons for receiving disability pension or causes of death, implying that the role of suspected causes of health variation is analyzed relying on indirect evidence only.

Disability pension is provided both as part of the national pension scheme, which encompasses all permanent residents in Finland, and as part of the employment pension scheme, which covers all employees, self-employed and farmers. In the national pension scheme, disability pension is awarded to "someone who has been found unfit for work", whereas in the employment pension scheme to "an employee with permanent reduced or lost work capacity, due to illness, defect or injury" (Central Pension Security Institute 1996). For our purposes, there is no need to distinguish between the two schemes. Becoming a disability pensioner reflects a health condition that, on reasonably objective grounds, allows for a permanent or temporal withdrawal from the labor market. 
The data allow for an analysis according to what is described in Figure 2. There are three potential health states: (0) "Healthy", i.e., not retired due to disability, (1) "Disabled", i.e., retired due to disability, and the absorbing (2) "Dead". Disability retirement and mortality are treated as being two competing events. We analyse the underlying transition rates $\lambda^{01}$ and $\lambda^{02}$, which are the risk of becoming a disability pensioner and the mortality risk. The two events cannot be compiled into a single one without obtaining ambiguous estimates for the impact of explanatory variables.

Figure 2. Observational plan.

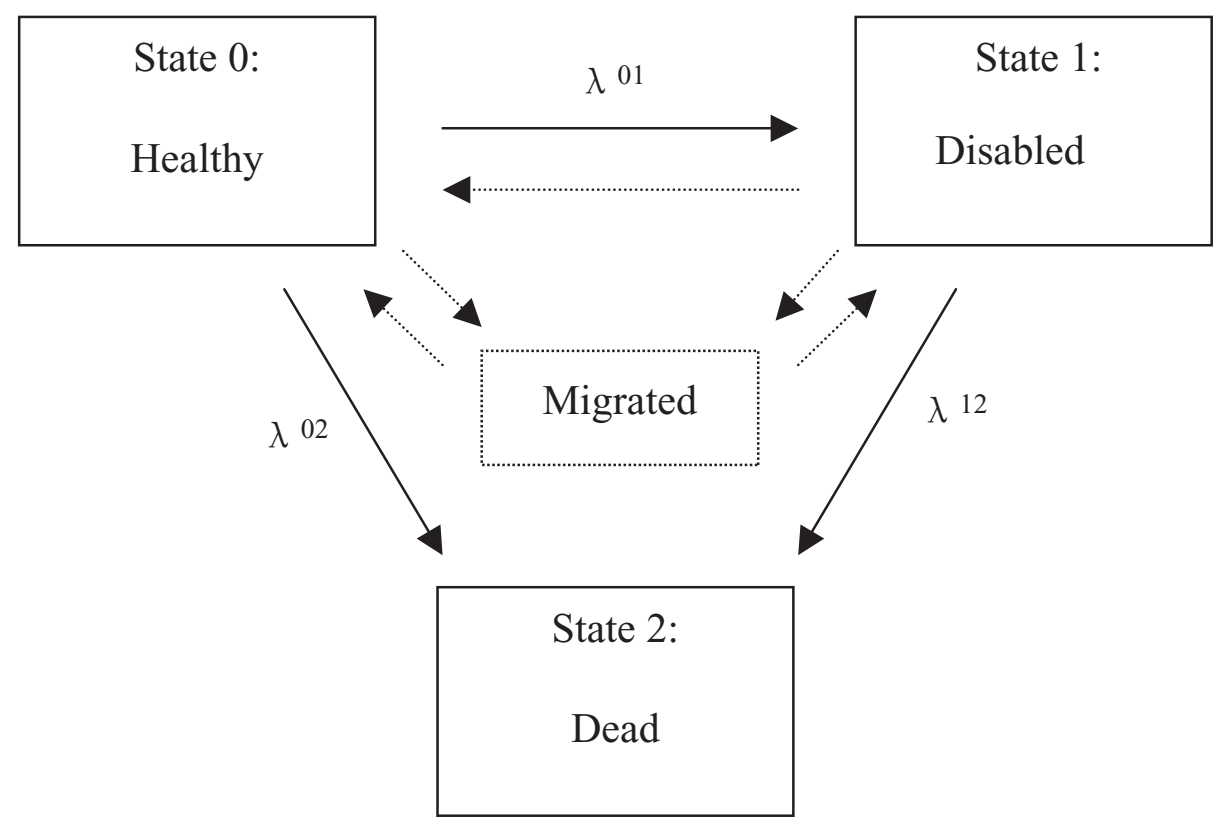

People studied are those aged 18-57. The reason behind this specific age restriction is that we analyze disability retirement propensity as an indicator of poor health, not as an outcome of the design of the pension scheme. People are not eligible to apply for disability pension before age 16 , which means that the retirement rate in ages 16-17 is exceptionally high due to an inflow from the stock of people with inborn handicaps. For people aged over 57, on the other hand, there are competing retirement programmes. These make the rate of disability retirement start falling after age 57, which consequently is not induced by an improved health of people in these ages (Note 1).

\section{Variable descriptions and distributions}

Table 1 provides a description of variable distributions by gender and population group, and age-standardised disability retirement rates and mortality rates in each socio-demographic subgroup. 
Table 1. Distribution of variables by gender and population group (\%), and agestandardised disability rates (D) and mortality rates (M) in each category (\%).

\begin{tabular}{|c|c|c|c|c|c|c|c|c|c|c|c|c|}
\hline & \multicolumn{6}{|c|}{ Men } & \multicolumn{6}{|c|}{ Women } \\
\hline & \multicolumn{3}{|c|}{ Finnish } & \multicolumn{3}{|c|}{ Swedish } & \multicolumn{3}{|c|}{ Finnish } & \multicolumn{3}{|c|}{ Swedish } \\
\hline & $\%$ & $\mathrm{D}$ & M & $\%$ & D & M & $\%$ & D & M & $\%$ & D & M \\
\hline \multicolumn{13}{|l|}{ Education } \\
\hline Basic & 30.9 & 12.4 & 4.2 & 33.5 & 9.2 & 2.6 & 29.5 & 11.0 & 1.4 & 31.2 & 8.3 & 1.0 \\
\hline Lower vocational & 41.8 & 6.0 & 2.1 & 39.6 & 3.5 & 1.5 & 39.7 & 4.6 & 0.8 & 39.6 & 3.3 & 0.6 \\
\hline Upper vocational & 10.8 & 5.2 & 1.4 & 11.4 & 3.5 & 1.5 & 16.5 & 3.0 & 0.5 & 15.6 & 3.6 & 0.4 \\
\hline $\begin{array}{l}\text { Undergraduate or } \\
\text { higher }\end{array}$ & 16.6 & 3.0 & 1.4 & 15.6 & 2.2 & 1.1 & 14.3 & 2.6 & 0.8 & 13.6 & 1.7 & 0.9 \\
\hline \multicolumn{13}{|l|}{ Family } \\
\hline Partner, child(ren) & 38.4 & 6.1 & 1.4 & 46.0 & 4.8 & 1.4 & 37.6 & 3.8 & 0.7 & 46.8 & 3.3 & 0.5 \\
\hline Partner, no children & 21.2 & 10.2 & 2.4 & 15.9 & 7.4 & 2.0 & 21.8 & 9.5 & 1.1 & 18.4 & 7.8 & 0.8 \\
\hline $\begin{array}{l}\text { Single or sole } \\
\text { supporter }\end{array}$ & 23.9 & 9.8 & 4.6 & 16.0 & 7.0 & 3.2 & 30.7 & 7.5 & 1.3 & 20.5 & 6.5 & 1.3 \\
\hline Other & 16.4 & 4.4 & 2.8 & 22.1 & 2.3 & 1.2 & 9.9 & 2.0 & 0.5 & 14.4 & 1.9 & 0.5 \\
\hline \multicolumn{13}{|l|}{ Previous status } \\
\hline Employed & 75.4 & 5.8 & 1.7 & 79.1 & 4.2 & 1.6 & 76.1 & 5.1 & 0.9 & 75.1 & 3.9 & 0.7 \\
\hline Unemployed & 11.3 & 5.2 & 7.3 & 7.0 & 3.3 & 3.7 & 7.4 & 4.1 & 1.2 & 5.7 & 5.0 & 1.2 \\
\hline Outside labor market & 13.3 & 17.5 & 3.5 & 13.9 & 13.6 & 2.1 & 16.4 & 10.7 & 1.0 & 19.2 & 7.7 & 0.7 \\
\hline \multicolumn{13}{|l|}{ Origin } \\
\hline Same region (1) & 53.1 & 6.7 & 2.5 & 90.2 & 4.9 & 1.7 & 47.1 & 4.6 & 0.9 & 88.2 & 4.4 & 0.7 \\
\hline $\begin{array}{l}\text { Other region in } \\
\text { the area (2) }\end{array}$ & 4.4 & 6.4 & 2.1 & 7.8 & 4.5 & 1.6 & 4.6 & 5.1 & 0.4 & 9.4 & 4.6 & 0.5 \\
\hline $\begin{array}{l}\text { Other Western } \\
\text { Finland (3) }\end{array}$ & 18.9 & 7.2 & 2.4 & 1.1 & 4.6 & 3.6 & 21.1 & 6.6 & 0.8 & 1.3 & 2.9 & 1.7 \\
\hline Eastern Finland (4) & 16.2 & 10.8 & 3.5 & 0.7 & 5.9 & 3.0 & 19.2 & 9.1 & 1.5 & 0.8 & 3.7 & 1.4 \\
\hline Northern Finland (5) & 7.4 & 9.4 & 2.6 & 0.1 & 8.8 & 2.0 & 8.1 & 6.6 & 0.9 & 0.3 & 1.2 & - \\
\hline Total & & 6.9 & 2.5 & & 5.5 & 1.8 & & 5.6 & 0.9 & & 5.0 & 0.8 \\
\hline Number of events & \multicolumn{4}{|c|}{$1,246 / 447$} & \multicolumn{2}{|c|}{837 / 282} & \multicolumn{3}{|c|}{$1,059 / 173$} & \multicolumn{3}{|c|}{$724 / 111$} \\
\hline Person-years & \multicolumn{4}{|c|}{179,310} & \multicolumn{2}{|c|}{152,210} & \multicolumn{3}{|c|}{189,338} & \multicolumn{3}{|c|}{145,564} \\
\hline Number of individuals & \multicolumn{4}{|c|}{23,717} & \multicolumn{2}{|c|}{17,709} & \multicolumn{3}{|c|}{24,787} & \multicolumn{3}{|c|}{16,960} \\
\hline
\end{tabular}

Notes: Persons included are those living in the area with Swedish-speaking settlement. Given this restriction on region of residence, "Origin" refers to persons born in

(1) the same region as now residing

(2) any other region in the area studied

(3) western Finland, outside the area studied

(4) eastern Finland

(5) northern Finland.

See also Figure 1. 
The aspect of central interest is birth region in relation to present region of residence. Due to the extensive migration into the area under study, birth regions include all parts of the country. Based on experimentation and in relation to previous research results, we found that these can be assigned into three larger geographical areas, referred to as western Finland, eastern Finland and northern Finland (Figure 1). Further, we separated people born in the same region as they presently are living from those born in any other region in the area studied. "Origin" therefore has five categories.

Almost all Swedish speakers originate from their present region of residence. In order to avoid structural zeroes, or at least very few observations in some subgroups, we therefore, for the purpose of statistical analysis, constructed a new variable that combined "Origin" and population group. The variable consequently separates between (1) Swedish speakers irrespective of birth region, and Finnish speakers born in (2) western Finland, (3) eastern Finland and (4) northern Finland, as illustrated by the broken lines in the table. Considering the sample size, this categorisation is obviously the one to be preferred. We did not find any significant variation in health between Swedish speakers born in the present region of residence and in-migrated ones, or between Finnish speakers born in the present region of residence and those born in other parts of western Finland.

Swedish speakers and Finnish speakers differ substantially on geographical distribution within the area studied (Saarela and Finnäs 2005). Having controlled for birth region, region of residence turned out not to be important, however, and it was therefore left out of the final models presented here.

Poor living conditions, unemployment and the presence of a partner are known to be highly correlated with death rates (Koskenvuo et al. 1981; Valkonen 1982; Näyhä 1989; Lynch et al. 1994; Martikainen and Valkonen 1996). To account for the impact of such socio-economic and demographic factors we have included control variables that represent each person's educational level (basic, lower vocational, upper vocational, undergraduate, or higher), recent labor market status (employed, unemployed, or outside the labor market), and family situation (partner and children, partner but no children, single or sole supporter, or others). As shown by the table and previous results (Saarela and Finnäs 2003a; 2003b), the two population groups differ on these characteristics.

\section{Statistical methods}

The independent competing risks model (Note 2) to be estimated can be described as

$$
\ln h_{i}^{k=1,2}(t)=\Gamma_{k}(t)+\beta_{k}^{\prime} X_{i(t)}+\varepsilon_{i}
$$

where $\ln h_{i}^{k=1,2}(t)$ is the log-hazard that an individual becomes a disability pensioner $(\mathrm{k}=1)$ or dies $(\mathrm{k}=2)$ between the end of two consecutive years. The baseline hazard, 
$\Gamma(t)$ captures duration dependency on respondent age (in the analysis modelled as age minus 18), and is assumed piecewise linear. We present results for the case where we have estimated the baseline hazard without nodes, i.e., with one parameter for the age dependency, as this fits the log-linear relationship between age and health observed in the data (see Figures 3 and 4). A vector of potentially time-varying explanatory variables is referred to as $\mathrm{X}$, whereas $\beta$ is its associated vector of coefficients. Since people in the data may experience more than one risk spell, in case they return from disability retirement (2,753 individuals experience two risk spells, 102 individuals three risk spells, and four individuals four risk spells), we incorporate a component for individual-specific unobserved heterogeneity. It is denoted by $\varepsilon_{i}$, and is assumed to be normally distributed with zero mean. The time-specific residual is suppressed for simplicity. All estimations have been carried out with the program aML 1.04.

\section{Results}

In line with previous studies, the data reveal that Swedish speakers have lower disability retirement and mortality rates than Finnish speakers (Figures 3 and 4). The between-group differential is generally also larger for men than for women, which implies that separate regressions must be estimated for each gender. Disability retirement is even less common an event in older Swedish-speaking men than in older Finnish-speaking women.

Figure 3 . Annual disability retirement rate in ages $18-57$, by gender and population group (five-year-period moving average).

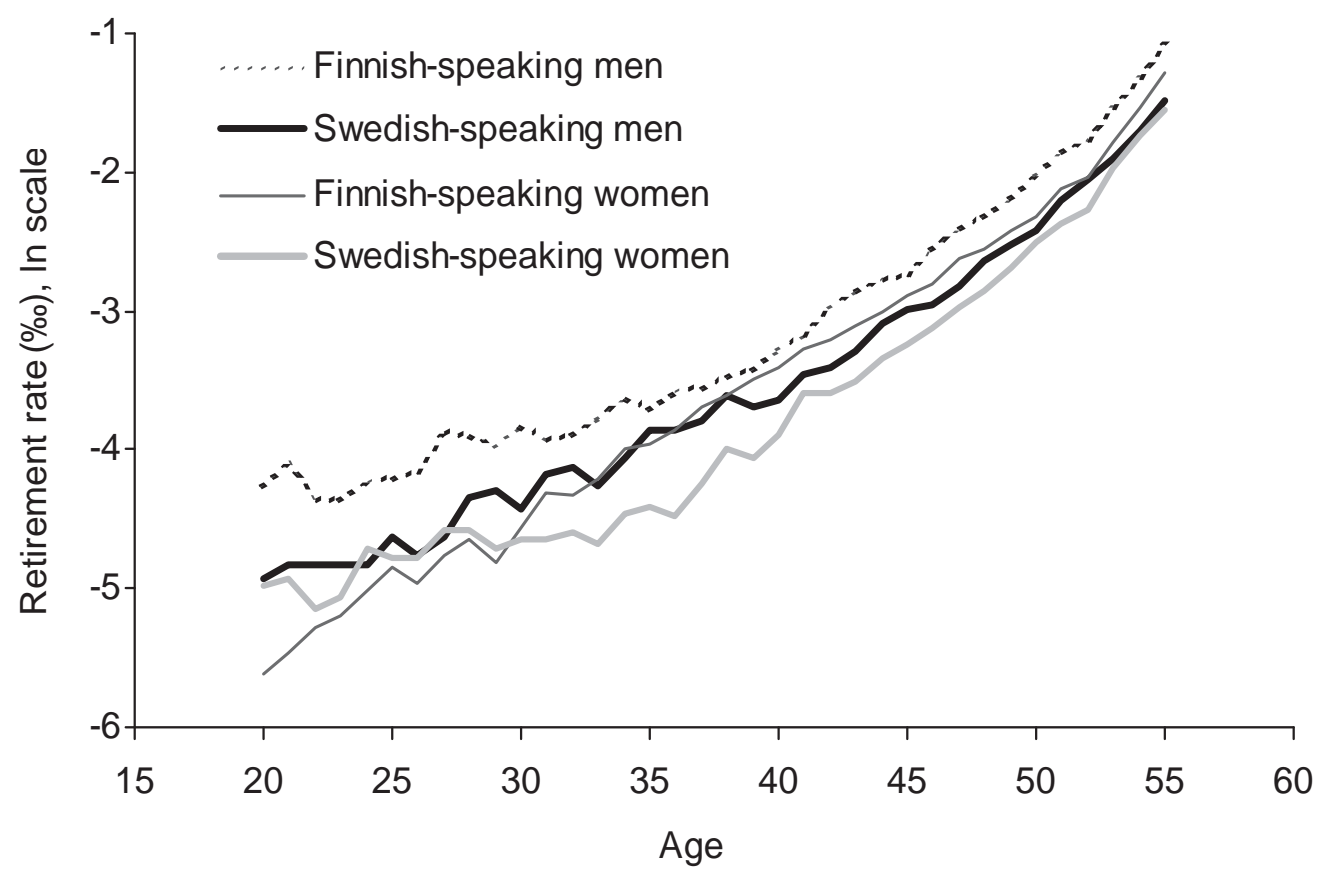


Figure 4. Annual mortality rate in ages $18-57$, by gender and population group (five-year-period moving average).

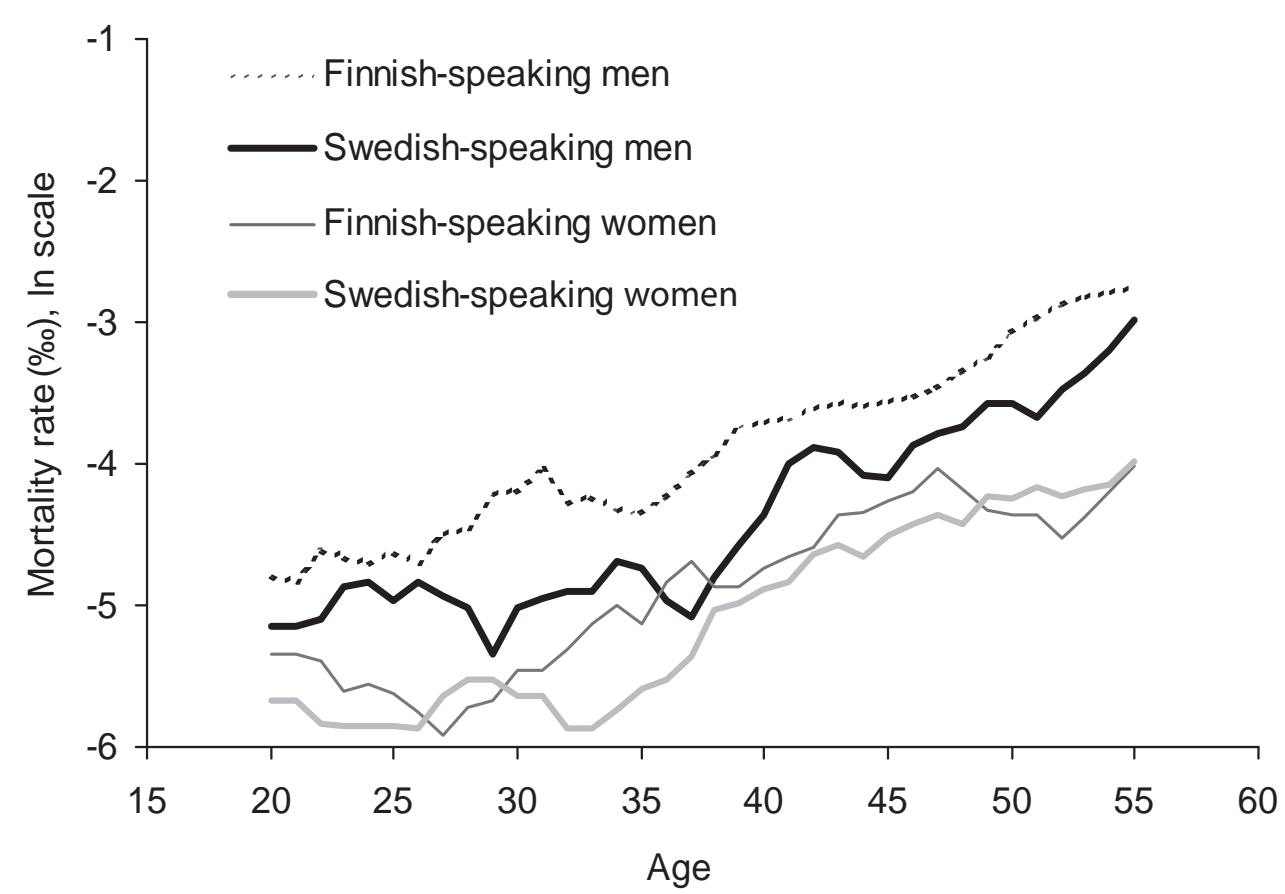

Effects of the control variables on overall mortality and disability retirement are strong and very much as expected. The incidence of each event decreases with educational level, and is higher for persons who live without children and a partner, and for those who recently have been unemployed or outside the labor market, as compared with others. To illustrate these variables' effect on the population-group health differential, we initially mention a few results not to be reported in further detail. The estimate for the impact of being a Finnish speaker, in comparison with being a Swedish speaker, on the log-hazard for male disability retirement is 0.4688 in a model without explanatory variables. This means that among Finnish-speaking men risk of early retirement is $1.60(\exp [0.4688])$ times that among Swedish-speaking men. When all variables except region of birth are added to the model, the estimate reduces only to 1.56. Corresponding changes in estimates for men's mortality rates are 1.49 to 1.39 , for women's disability retirement rates 1.37 to 1.32 , and for women's mortality rates 1.27 to 1.19 . Thus in spite of the fact that age, educational level, family situation and recent labor market status have significant effects on the overall fit of the models, their contribution to the population-group health differential is very small.

The results from models in which all variables have been included are in turn presented in Table 2. Here, the indicator for whether the person is Finnish-speaking is now substituted with the variable that combines population group and geographical extraction. We can see that among Finnish-speaking men the risk of disability retirement for those born in western Finland is $1.43(\exp [0.3611])$ times that of Swedish-speaking men. 
Accounting for geographical extraction consequently reduces the population-group health differential remarkably, recalling that when this variable was not adjusted for the corresponding factor was 1.56. The estimates for Finnish-speaking men from eastern and northern Finland are 1.74 and 2.11, respectively, clearly indicating that birth region is important. The adjusted retirement risk for Finnish speakers originating from northern Finland is therefore 47.6 percent higher (2.11/1.43), and for those originating from eastern Finland 21.7 percent higher (1.74/1.43), than for those originating from western Finland. Very much the same pattern is found for mortality among men and women as well as disability retirement among women.

Table 2. Hazard model results for disability retirement and for mortality.

\begin{tabular}{|c|c|c|c|c|}
\hline & \multicolumn{2}{|c|}{ Men } & \multicolumn{2}{|c|}{ Women } \\
\hline & Disability & Mortality & Disability & Mortality \\
\hline Finnish speaker from Western Finland & $\begin{array}{r}0.3611 \\
(0.0799)\end{array}$ & $\begin{array}{r}0.2791 \\
(0.1180)\end{array}$ & $\begin{array}{r}0.1745 \\
(0.0874)\end{array}$ & $\begin{array}{r}0.0735 \\
(0.1971)\end{array}$ \\
\hline Finnish speaker from Eastern Finland & $\begin{array}{r}0.5565 \\
(0.0949)\end{array}$ & $\begin{array}{r}0.4941 \\
(0.1389)\end{array}$ & $\begin{array}{r}0.4545 \\
(0.0996)\end{array}$ & $\begin{array}{r}0.4249 \\
(0.2233)\end{array}$ \\
\hline Finnish speaker from Northern Finland & $\begin{array}{r}0.7477 \\
(0.1189)\end{array}$ & $\begin{array}{r}0.3399 \\
(0.1894)\end{array}$ & $\begin{array}{r}0.4486 \\
(0.1269)\end{array}$ & $\begin{array}{r}0.0184 \\
(0.3059)\end{array}$ \\
\hline Lower vocational education & $\begin{array}{l}-0.3876 \\
(0.0582)\end{array}$ & $\begin{array}{l}-0.3616 \\
(0.0875)\end{array}$ & $\begin{array}{l}-0.3507 \\
(0.0651)\end{array}$ & $\begin{array}{r}-0.1464 \\
(0.1418)\end{array}$ \\
\hline Upper vocational education & $\begin{array}{l}-1.2018 \\
(0.1654)\end{array}$ & $\begin{array}{l}-1.0498 \\
(0.2570)\end{array}$ & $\begin{array}{l}-0.9615 \\
(0.1630)\end{array}$ & $\begin{array}{l}-1.1076 \\
(0.3953)\end{array}$ \\
\hline Undergraduate or higher education & $\begin{array}{l}-1.5837 \\
(0.1189)\end{array}$ & $\begin{array}{l}-0.8508 \\
(0.1575)\end{array}$ & $\begin{array}{l}-1.2644 \\
(0.1241)\end{array}$ & $\begin{array}{l}-0.5553 \\
(0.2384)\end{array}$ \\
\hline Partner and no children & $\begin{array}{r}0.3275 \\
(0.0778)\end{array}$ & $\begin{array}{r}0.6163 \\
(0.1204)\end{array}$ & $\begin{array}{r}0.6060 \\
(0.0812)\end{array}$ & $\begin{array}{r}0.6649 \\
(0.1833)\end{array}$ \\
\hline Single or sole supporter & $\begin{array}{r}0.4545 \\
(0.0697)\end{array}$ & $\begin{array}{r}1.0103 \\
(0.1105)\end{array}$ & $\begin{array}{r}0.6502 \\
(0.0725)\end{array}$ & $\begin{array}{r}0.7825 \\
(0.1576)\end{array}$ \\
\hline Other & $\begin{array}{r}0.5221 \\
(0.1000)\end{array}$ & $\begin{array}{r}0.9906 \\
(0.1429)\end{array}$ & $\begin{array}{r}1.0834 \\
(0.1407)\end{array}$ & $\begin{array}{r}-0.0974 \\
(0.3026)\end{array}$ \\
\hline Unemployed & $\begin{array}{r}0.9399 \\
(0.1066)\end{array}$ & $\begin{array}{r}1.0873 \\
(0.1445)\end{array}$ & $\begin{array}{r}0.7499 \\
(0.1410)\end{array}$ & $\begin{array}{r}1.0540 \\
(0.2900)\end{array}$ \\
\hline Outside labor market & $\begin{array}{r}1.5142 \\
(0.0818)\end{array}$ & $\begin{array}{r}0.5397 \\
(0.1305)\end{array}$ & $\begin{array}{r}0.9233 \\
(0.0878)\end{array}$ & $\begin{array}{r}0.4685 \\
(0.1903)\end{array}$ \\
\hline Age & $\begin{array}{r}0.1561 \\
(0.0043)\end{array}$ & $\begin{array}{r}0.0859 \\
(0.0057)\end{array}$ & $\begin{array}{r}0.1643 \\
(0.0049)\end{array}$ & $\begin{array}{r}0.0657 \\
(0.0091)\end{array}$ \\
\hline Constant & $\begin{array}{r}-10.5339 \\
(0.2138)\end{array}$ & $\begin{array}{l}-9.7111 \\
(0.5156)\end{array}$ & $\begin{array}{r}-11.1318 \\
(0.2426)\end{array}$ & $\begin{array}{r}-11.2331 \\
(1.8287)\end{array}$ \\
\hline Unobserved individual heterogeneity & $\begin{array}{r}1.5881 \\
(0.0677)\end{array}$ & $\begin{array}{r}1.4378 \\
(0.2852)\end{array}$ & $\begin{array}{r}1.6149 \\
(0.0742)\end{array}$ & $\begin{array}{r}2.1851 \\
(0.8795)\end{array}$ \\
\hline Log likelihood & $-11,586.6$ & $-5,230.1$ & $-9,870.3$ & $-2,287.9$ \\
\hline $\begin{array}{l}\text { Person-years } \\
\text { Number of individuals }\end{array}$ & \multicolumn{2}{|c|}{331,521} & \multicolumn{2}{|c|}{334,902} \\
\hline
\end{tabular}

Notes: Standard errors are in parentheses. In each of the four models, all variables have been entered simultaneously. Reference categories used are "Swedish speaker", "Basic education", "Partner and child(ren)", "Employed". 
Finnish speakers from western Finland are consequently healthier than those from eastern and northern Finland. Still, we cannot statistically discriminate the latter two from each other, and there remains a significant difference between Swedish speakers and Finnish speakers originating from western Finland. However, for women's mortality, it is close to zero (see Table 3).

It ought to be remembered, however, that in these ages the total number of disability pensioners and the total number of deaths is relatively small. To give an idea about the meaning of our results in cumulative numbers, we have in Table 3 outlined the proportion of people in the reference categories, who would have retired due to disability and to have died at age 57 . One can see that whereas six percent of the Swedish-speaking men would have retired due to disability, the corresponding proportion among Finnish-speaking men born in western Finland is eight percent, and even higher for Finnish-speaking men from eastern Finland and northern Finland, or ten and eleven percent, respectively. Similar relative differences between subgroups are observed in disability retirement among women as well as in mortality among men and women.

Table 3. Proportion of people expected to having retired due to disability and to having died at age $57(\%)$.

\begin{tabular}{lcccccc}
\hline & \multicolumn{2}{c}{ Men } & & \multicolumn{2}{c}{ Women } \\
\cline { 2 - 3 } \cline { 5 - 6 } & Disability & Mortality & & Disability & Mortality \\
\hline Swedish speakers & 55.8 & 7.2 & & 43.7 & 1.5 \\
Finnish speakers from western Finland & 79.0 & 9.6 & & 51.8 & 1.6 \\
Finnish speakers from eastern Finland & 95.3 & 11.9 & & 67.9 & 2.3 \\
Finnish speakers from northern Finland & 114.2 & 10.2 & & 67.5 & 1.6 \\
\hline
\end{tabular}

Note: Calculations are based on the estimation results presented in Table 2 and refer to an individual with the reference characteristics.

\section{Conclusions}

This study suggests that conditions at early childhood, in our case reflected by region of birth, seem to have a substantial impact on adult health. As Swedish speakers and Finnish speakers in Finland differ remarkably with respect to geographical extraction, a consequence for research concerned with the population-group health differential is that it is not sufficient to eliminate the effects of regional variation simply by restricting analysis to people living in the same regions. An important element underlying the higher mortality and disability retirement rates of Finnish speakers is that a considerable proportion of them originate from eastern and northern Finland. For Finnish speakers born in western Finland, the difference in relation to Swedish speakers is clearly smaller. 
There are several potential explanations to our findings. One is that socio-economic circumstances operating at childhood may affect adult health (Elo and Preston 1992; Lynch et al. 1994). Notkola et al. (1985), for instance, show that the excess mortality in eastern Finland was accentuated among sons of landless. In the regions studied here, geographical extraction could therefore potentially reflect differences in socio-economic environment at early age. Another is that people born outside the present region of residence are less integrated in the local society than others. Such social disintegration may lead to feelings of alienation or social isolation, and affect health and well-being (Kawachi and Kennedy 1997; Kawachi et al. 1997). Considering that there at the national level is regional variation in specific causes of death (Valkonen 1987; Koskinen 1994), we additionally find it plausible that the distribution of hereditary diseases varies regionally. There seems to be some disagreement, however, about whether the population of Finland is genetically homogeneous and how genetic variation affects health (Virtaranta-Knowles, Sistonen, and Nevanlinna 1991; Koskinen 1994).

One may also note that our results contradict the hypothesis of a healthy migrant effect (Friis, Yngve, and Persson 1998). If migrants were positively selected with respect to health, differences between Finnish speakers and Swedish speakers found here ought to be in the opposite direction. One could also expect that Swedish speakers in the area would have relatively poor health as they constitute the remainder of an extensive migration abroad.

Still, it ought to be borne in mind that a non-negligible part of the population-group health differential is left unexplained. Understanding this residual is a challenging task. Recalling that the present paper has studied only working-aged people, in which the total death rate is low, and since we are not willing to oversee the role of hereditary factors, shifting the foci towards older persons might provide some further evidence.

It cannot, however, be ruled out that health behaviors and risk factors associated with differing lifestyles underlie the health variation. Being born in a specific area may not be related only to one's genes and physical resources, but also to attitudes, social skills and self-esteem, which could be relevant to health. These factors may be mediated by health behaviors and therefore potentially explain part of the residual difference between the two population groups. Analyses of cause-specific mortality have revealed that cardiovascular diseases, which often are assumed to reflect smoking patterns and unhealthy dietary habits, are less common in the Swedish-speaking population than in the Finnish-speaking one (Koskinen 1994; Näyhä 1989; Koskinen and Martelin 2003). There are also some indications that excessive alcohol consumption and non-natural causes of death, such as violent, accidental death and suicide, are more prevalent in Finnish-speaking males than in Swedish-speaking males (Valkonen 1982; Simpura 1990; Salminen et al. 1996; Koskinen and Martelin 2003). 
The road map for future analysis is consequently diversified. More detailed analysis may obviously benefit from information about causes of death, diagnoses for disability pension and more general measures of health status. Other ways of measuring geographical extraction may also, however, provide gainful insights into the role of hereditary factors. One possibility could be to use intergenerational data.

\section{Acknowledgments}

Comments from anonymous persons and Stan Panis, as well as seminar participants at the Turku Center for Welfare Research, Växjö University, the 17th Nordic Conference in Social Medicine and Public Health and Panel 2004, have been helpful. Jan Saarela gratefully acknowledges financial support from Signe och Ane Gyllenbergs Stiftelse.

\section{Notes}

1. Due to the competing retirement programmes, the average age of permanent retirement in Finland is 59 years, albeit it is not possible to receive old-age pension before age 65 .

2. Originally, we tried to estimate the two types of transitions as dependent risks, but that changed the estimation results only marginally.

\section{References}

Central Pension Security Institute [Finland]. 1996. Statistical Yearbook of Pensioners in Finland 1995. Helsinki.

Elo, I. T. and S. Preston. 1992. Effects of Early-life Conditions on Adult Mortality: A Review. Population Index 58:186-212.

Finnäs, F. 1986. Den finlandssvenska befolkningsutvecklingen 1950-1980. En analys av en språkgrupps demografiska utveckling och effekten av blandäktenskap. Doctoral Dissertation. Skrifter utgivna av svenska litteratursällskapet i Finland, Nr. 533. Helsinki: Svenska litteratursällskapet i Finland.

Friis, R., A. Yngve and V. Persson. 1998. Review of Social Epidemiologic Research on Migrants' Health: Findings, Methodological Cautions, and Theoretical Perspectives. Scandinavian Journal of Social Medicine 26:173-180.

Kawachi, I., and B.P. Kennedy. 1997. Socioeconomic Determinants of Health: Health and Social Cohesion: Why Care About Income Inequality? British Medical Journal 314:1037.

Kawachi, I., B.P. Kennedy, K. Lochner and D. Prothrow-Stith. 1997. Social Capital, Income Inequality, and Mortality. American Journal of Public Health 87:1491-1498.

Koskenvuo, M., J. Kaprio, M. Romo and H. Langinvainio. 1981. Incidence and Prognosis of Ischaemic Heart Disease with Respect to Marital Status and Social Class, a National Record Linkage Study. Journal of Epidemiology and Community Health 35:192-196.

Koskinen, S. 1994. Origin of Regional Differences in Mortality from Ischaemic Heart Disease in Finland. Doctoral Dissertation. Research Reports, No. 41. Jyväskylä: National Research and Development Centre for Welfare and Health. 
Koskinen, S.and T. Martelin. 1994. Kuolleisuus. In: Suomen Väestö, edited by S. Koskinen, T. Martelin, I-L. Notkola, V. Notkola, and K. Pitkänen, pp. 150-225. Hämeenlinna: Gaudeamus.

Koskinen, S. and T. Martelin. 2003. Why is Mortality Low among the Swedish-speaking Minority in Finland? Yearbook of Population Research in Finland 39:15-32.

Lynch, J. W., G.A. Kaplan, R.D. Cohen, T.W. Wilson, N.L. Smith, J. Kauhanen, and J.T. Salonen. 1994. Childhood and Adult Socioeconomic Status as Predictors of Mortality in Finland. Lancet 343:524-527.

Martelin, T. 1994. Differential Mortality at Older Ages. Doctoral Dissertation. Publications of the Finnish Demographic Society, No. 16. Helsinki: Finnish Demographic Society.

Martikainen, P. T., Valkonen T. 1996. Excess Mortality of Unemployed Men and Women during A Period of Rapidly Increasing Unemployment. Lancet 348:909-912.

Notkola, V., S. Punsar, M. Karvonen, and J. Haapakoski. 1985. Socioeconomic Conditions in Childhood and Mortality and Morbidity Caused by Coronary Heart Disease in Adulthood in Finland. Social Science \& Medicine 21:517-523.

Näyhä, S. 1989. Geographic Variations in Cardiovascular Mortality in Finland 1961-1985. Scandinavian Journal of Social Medicine Supplementum 40.

Saarela, J. and F. Finnäs. 2002. Population-group Differences in very early Retirement in Finland. Demographic Research 7:49-66.

Saarela, J. and F. Finnäs. 2003a. Unemployment and Native Language: The Finnish Case. Journal of Socio-Economics 32:59-80.

Saarela, J. and F. Finnäs. 2003b. Social Background and Education of Swedish and Finnish Speakers in Finland. European Journal of Education 38:445-456.

Saarela, J. and F. Finnäs. 2005. Can the Low Unemployment Rate of Swedish-speakers in Finland be Attributed to Structural Factors? Journal of Socio-Economics, forthcoming.

Salminen, S., A. Johansson, E. Hiltunen, and F. Strømnes. 1996. Suomen- ja ruotsinkielisten työntekijöiden tapaturmasuhteet. Työ ja Ihminen 10:125-136.

Sauli, H. 1979. Ammatti ja kuolleisuus 1971-75. Research Reports, No. 54. Helsinki: Statistics Finland.

Simpura, J. 1990. Hur dricker finlandssvensken? Finska Läkarsällskapets Handlingar 150:168-170.

Statistics Finland [Finland]. 1997. Life Tables. Population 1997:4. Helsinki.

Statistics Finland [Finland]. 2005. Rekisteriseloste: Väestölaskentojen pitkittäistiedosto 1970-1995.Available from:

www.stat.fi/meta/rekisteriselosteet/rekisteriseloste_vaestolaskenta70-95.html [cited 17 June 2005].

Valkonen, T. 1982. Psychosocial Stress and Sociodemographic Differentials in Mortality from Ischeamic Heart Disease in Finland. Acta Medica Scandinavica 660:152-164.

Valkonen, T. 1987. Male Mortality from Ischaemic Heart Disease in Finland: Relation to Region of Birth and Region of Residence. European Journal of Population 3:61-83.

Virtaranta-Knowles, K., P. Sistonen, and H.R. Nevanlinna. 1991. A Population Genetic Study in Finland: Comparisons of the Finnish- and Swedish-speaking Populations. Human Heredity $41: 248-264$. 